UDC 615.12:658.8:[004.451:621.395.721.5

https://doi.org/10.32345/USMYJ.4(127).2021.84-91

Received: July 3,2021

Accepted: August 30,2021

\title{
ANALYSIS OF THE USE OF MOBILE APPLICATIONS BY FOREIGN AND UKRAINIAN PHARMACIES WITHIN THE CONCEPT OF HOLISTIC MARKETING
}

\author{
Sakhnatska Nataliia ${ }^{1}$, Aliekperova Nataliia ${ }^{2}$ \\ ${ }^{1}$ Assistant of the Department of Organization and Economics of Pharmacy, Bogomolets National Medical \\ University, Kyiv, Ukraine. \\ ${ }^{2}$ Candidate of Pharmaceutical Sciences, Associate Professor of the Department of Organization and \\ Economics of Pharmacy, Bogomolets National Medical University, Kyiv, Ukraine.
}

\begin{abstract}
: digitalization of the pharmaceutical sector requires the use of modern marketing approaches to provide pharmacies with quality and safe pharmaceutical care within the holistic concept of marketing management. A promising direction of digital transformation of the retail market of medicines is the introduction of special mobile applications in the activities of pharmacies, which become a safe and accessible platform for the sale of medicines to the population.

The main purpose of the study is to exercise the analysis of the features of pharmaceutical services provision using mobile applications to foreign and Ukrainian pharmacy chains.

The study is based on the use of content analysis, analysis of electronic resources, system, and logical analysis, as well as of the modeling method.

As the objects of the study, American pharmacy chains CVS Pharmacy and Walgreens, British Boots, and Lloyds Pharmacy were selected, as well as 10 pharmacy chains in Ukraine in terms of turnover in January-October 2020.

It is revealed that the leading world leaders in the retail market of medicines have been using this digital tool in their marketing activities for a long time. Unlike domestic pharmacies, applications of foreign pharmacies additionally provide such services as online registration for testing and vaccination against COVID-19, additional opportunities for the visually impaired, drug disposal, and others. Among the studied Ukrainian pharmacy chains by market share, only a half have mobile applications with various functions, among the most developed mobile applications are "Like" from LLC "Apteka-Magnolia" ("Pharmacy-Magnolia"), "Pharmacy 911" and "Apteka Dobroho Dnia" ("Good Afternoon Pharmacy").

An integrated model of a mobile application of a modern pharmacy has been developed, aimed at effective interaction of all necessary functions to provide the population with high-quality, convenient, and available pharmaceutical care. Promising areas of further research are the justification of the feasibility of using certain functions of mobile applications, as well as other digital tools, such as pharmacy websites, social media pages within the concept of holistic marketing.

The results of the study conducted may be useful to specialists in the pharmaceutical industry for use in practical pharmacy.
\end{abstract}

Keywords. telemedicine, drug evaluation, mobile application, pharmaceutical preparations, pharmacy.

Introduction. The rapid development of digital technologies requires the use of modern marketing approaches to provide pharmacies with quality and safe pharmaceutical care, creating additional value for both new and regular customers within the holistic concept of marketing management and, as a consequence, the sustainable development of the pharmacy business (Sakhnatska, 2019). The global COVID-19 pandemic has made significant adjustments, having restricted the free movement of citizens, having changed the previously accepted way of life, and having endangered the lives and health of health professionals, including phar- macists. A promising and modern way to solve this problem is the integration into the activities of pharmacies of special mobile applications that become a safe and accessible platform for the sale of medicines to the public (Olkhovska, A. B., 2016). It should be noted that the use of these digital platforms is gaining popularity: according to the Research Holding Factum Group Ukraine, among active Internet users, almost $70 \%$ use mobile devices (smartphones and tablets) (Almost 23 million Ukrainians regularly use the Internet - research). The mentioned above determined the relevance of this study, its purpose, and its main tasks. 
The work aims to analyze the features of the provision of pharmaceutical services with the use of mobile applications of foreign and domestic pharmacy networks.

To achieve this goal it is necessary to solve the following tasks:

- to review the foreign experience of using mobile applications on the example of global pharmacy networks;

- to analyze the current state of use of mobile applications in the Ukrainian pharmacy market;

- to develop an integrated model of a mobile application for a domestic pharmacy.

Methods. The study used content analysis, analysis of electronic resources, system, and logical analysis, as well as the modeling method. To substantiate the feasibility of using mobile applications in the pharmacy sector, the experience of global and Ukrainian pharmacy networks has been analyzed, in the marketing activities of which a wide range of digital tools is introduced.

The objects of the study are the American pharmacy chains CVS Pharmacy and Walgreens, which occupy $24.8 \%$ and $19.1 \%$ of the US retail market, respectively (Top U.S. pharmacies ranked by prescription drugs market share in 2020 ) the British network of pharmacies Boots, which since 2014 is part of the international corporation Walgreens Boots Alliance, Lloyds Pharmacy, which has more than 1,400 pharmacies across the UK (World Top Pharmacy Companies List by Market Cap as on Jan 1st, 2020; About LloydsPharmacy, 2021) and 10 pharmacy chains in Ukraine in terms of turnover in January-October 2020 (Pharmacy market infrastructure: the evolutionary path of the retail segment consolidation, 2021) (Table 1).

\section{Results.}

1. Analysis of the content and functions of mobile applications of foreign pharmacy networks

\subsection{CVS Pharmacy}

CVS Pharmacy, part of the US healthcare corporation CVS Health, is a leader in the US pharmacy market that actively uses digital tools to meet the needs of its customers and build their loyalty. The CVS Pharmacy mobile application combines digital tools designed specifically to address the issues most commonly encountered by pharmacy customers, such as the ability to pre-order and receive medications at home without contact (Fig.1).

In the global pandemic conditions, CVS Pharmacy is also implementing projects related to coronavirus disease prevention, morbidity monitoring, and, directly, vaccination against COVID-19. With the help of the mobile application, it is possible to find the nearest testing point for COVID-19, indicating your address and zip code: about 5,000 pharmacies in 33 states of the United

\begin{tabular}{|c|c|c|c|c|}
\hline № & $\begin{array}{l}\text { Pharmacy network } \\
\text { (indicating the legal entity) }\end{array}$ & $\begin{array}{l}\text { City of } \\
\text { registration }\end{array}$ & $\begin{array}{l}\text { Market share } \\
\text { in total turnover, } \\
\text { percentage }\end{array}$ & $\begin{array}{l}\text { Number of outlets } \\
\text { (as of the end of } \\
\text { November 2020) }\end{array}$ \\
\hline 1. & $\begin{array}{l}\text { LLC “Apteka-Magnolia” ("Pharmacy-Magnolia"): } \\
\text { ("Apteka nyzkyh tsin" ("Low Prices Pharmacy «), } \\
\text { "Kopiyka" ("Penny”), "Blahodiya" ("Charity”)) } \\
\end{array}$ & Zaporizhia & 12,6 & 913 \\
\hline 2. & $\begin{array}{l}\text { LLC “Sirius-95” } \\
\text { ("Bazhayemo zdorovya” ("We wish you health")) }\end{array}$ & Kyiv & 9,7 & 836 \\
\hline 3. & $\begin{array}{l}\text { Private firm “Gamma-55" } \\
\text { (“Apteka 911” ("Pharmacy 911”)) }\end{array}$ & Kharkiv & 8,8 & 896 \\
\hline 4. & LLC "Podorozhnyk" ("Plantain") & Lviv & 6,4 & 815 \\
\hline 5. & $\begin{array}{l}\text { LLC "Pharmastor" } \\
\text { (“Apteka Dobroho Dnia" ("Good Aftrenoon Pharma- } \\
\text { cy"), "1 Sotsialna apteka" ("1 } 1 \text { st Social pharmacy")) }\end{array}$ & Kyiv & 4,3 & 414 \\
\hline 6. & \begin{tabular}{|l|} 
LLC “Med-Service Group” \\
(Apteky "Med-Service" \\
("Med-Service" Pharmacies)) \\
\end{tabular} & Dnipro & 2,3 & 341 \\
\hline 7. & $\begin{array}{l}\text { LLC "Market Universal LTD” } \\
\text { (D.S. Pharmacy Network) }\end{array}$ & Lviv & 2,0 & 275 \\
\hline 8. & $\begin{array}{l}\text { PJSC “AM Pharmacy" } \\
\text { (Farmacia family of pharmacies) }\end{array}$ & Odesa & 1,8 & 363 \\
\hline 9. & $\begin{array}{l}\begin{array}{l}\text { LLC "Pharmaceutical company "Zdorova rodyna" } \\
\text { ("Healthy Family") }\end{array} \\
\end{array}$ & \begin{tabular}{|l|} 
Ivano- \\
Frankivsk \\
\end{tabular} & 1,5 & 302 \\
\hline 10. & LLC “Apteka 3i” (“Pharmacy 3i”) & Mykolaiv & $<1,5$ & 299 \\
\hline
\end{tabular}

Table 1. Top 10 pharmacy chains in terms of turnover in January-October 2020 


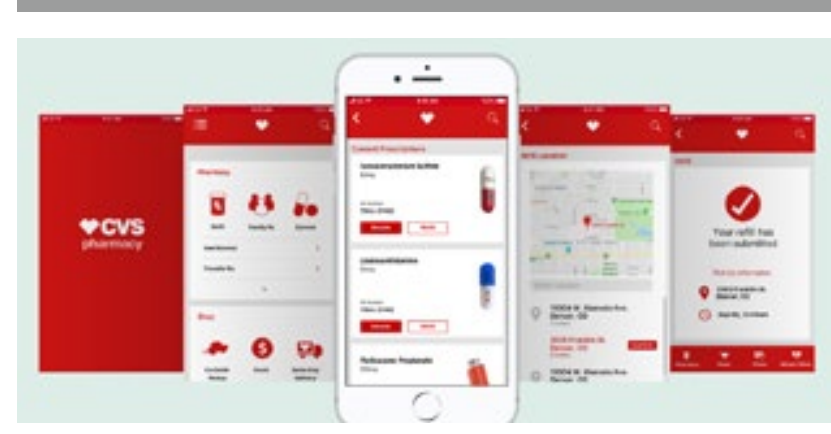

Fig.1. CVS Pharmacy mobile application interface

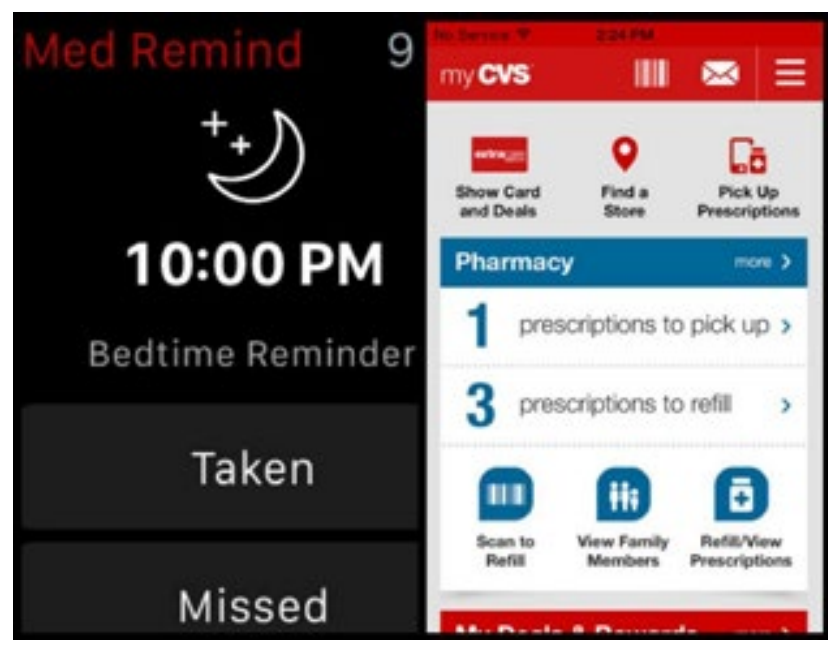

Fig.2. Med Remind function in the CVS Pharmacy application

States provide such a service. With the help of a mobile application, you can find the nearest vaccination point against COVID-19, track the name of the vaccine offered by a particular pharmacy, register in the electronic queue, come to the pharmacy on the selected date, and time (CVS Health).

A useful feature of the app is to help patients with compliance (MedRemind): reminders to take medication at the right time and notify contact persons (family members of the patient or the patient's friends) if the patient missed the drug (Fig. 2). Also, thanks to the integration of the application with the Apple Watch device, it is possible to receive reminders directly to this gadget.

The CVS Pharmacy network helps to remove potential barriers to the provision of medicines to customers with certain physical disabilities, such as visual impairments (Fig. 3). The innovative Spoken Rx function for reading the name of the drug is the result of cooperation between CVS pharmacies and the American Council of the Blind. It is available through Siri or Google Assistant on the smartphone. With the application, you can scan the RFID (Radio Frequency Identification) label and read the information about the drug aloud in English or Spanish.

\subsection{Walgreens}

The next object of our study was the American pharmacy chain Walgreens, which has been using the Wal-

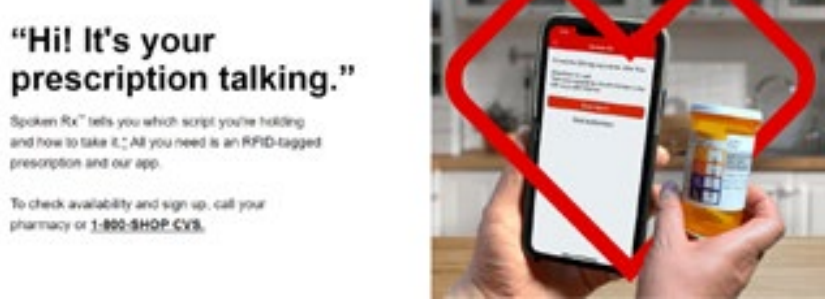

Fig.3. Spoken Rx function from the CVS Pharmacy pharmacy network

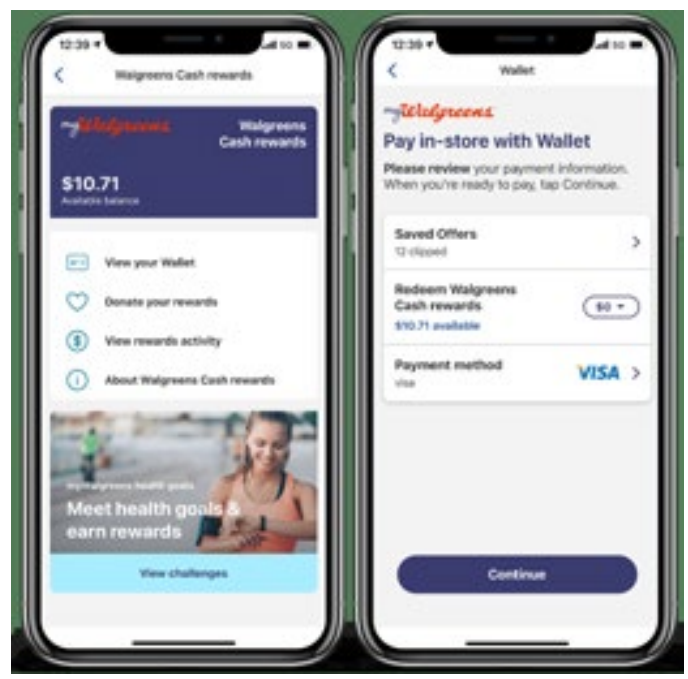

Fig.4. Walgreens mobile application interface

greens mobile application for a long time for the convenience and customer orientation of consumers (Fig. 4). With this application, you can accumulate points on a flexible loyalty system Walgreens Cash, receiving a bonus card of 10 points for every $\$ 1$ of your purchase, and for products of the pharmacy's brand you can get even $5 \%$ of the purchase amount (Walgreens: Pharmacy, Health \& Wellness, Photo \& More for You).

Besides, the advantage of this mobile application is the fast and contactless ordering and the ability to receive drugs even while driving a car by the use of the service Drive-thru pharmacy ("Pharmacy behind the wheel"), which is extremely relevant during the pandemic (Fig. 5).

With Walgreens' application, patients can also sign up for COVID-19 vaccination. The recording process is similar to the aforementioned CVS Pharmacy network. After the patient chooses the time, he/she will receive a confirmation and consent form for vaccination by e-mail or SMS.

\subsection{Boots UK}

The British pharmacy chain Boots UK, which became part of the international corporation Walgreens Boots Alliance (Mnushko Z.M., Aliekperova N.V., \& Pestun I.V., 2013) after Walgreens acquired a 55\% stake in the British and Swiss Alliance Boots, also interacts 
with its customers through digital tools. With the Boots Advantage mobile app (Boots: Beauty | Health | Pharmacy and Prescriptions) you can make online bookings of medicines or medical devices remotely, accumulate points on a bonus account, are aware of new products and promotional offers of the company, and set reminders to receive the drug, similar to the Med Remind function from CVS Pharmacy.

To raise citizens' environmental awareness as to recycling of used packaging, Boots UK has launched a new scheme for recycling plastic packaging using Scan2Recycle technology. Thuswise, Boots customers have the opportunity to return empty plastic containers of the goods, and in return receive points under the loyalty program, which they can then use to purchase drugs or medical devices. With the help of the Boots application, the user finds the nearest container by geolocation, registers online, scans the used packaging using a smartphone and QR-code on the container, and leaves it in a special box for disposal, which is located in the pharmacy (Fig. 6). Due to this, Boots UK promotes the implementation of the principles of social and ethical marketing, namely the environmental responsibility of business.

\subsection{LloydsPharmacy}

The British pharmacy company LloydsPharmacy, which is part of the American corporation McKesson, which is the third largest market capitalization in the world, uses the Echo mobile application in its activities (Fig. 7). It is worth noting that the above-mentioned mobile application is supported by the National Health Service of the United Kingdom (National Health Service) (LloydsPharmacy | Online Pharmacy, Prescriptions \& Health, 2021).

The peculiarity of this tool is that it works with a reimbursement system. Through the Echo supplement, the patient indicates which medication he needs to get again. He can enter the name of the drug himself or scan the barcode on the already used packaging. After receiving the order, the pharmacy specialists contact the patient's family doctor for confirmation. After checking the correctness of the appointment, the pharmacy staff sends an electronic prescription to the patient. After that, he can go to the nearest pharmacy (finding the address with the help of an online card in the application) and get the ordered medicine. It is also possible to deliver drugs by Royal Mail using convenient and safe packaging for mailboxes. 10 days before the full use of the drug package, the patient receives a reminder in the application about the need to order the next package of drugs. It should be noted that the effective use of this digital tool is possible only on the condition of close interaction of a doctor, a pharmacist, and a patient.

2. Analysis of the functions of mobile applications of Ukrainian pharmacy networks

In order to achieve the goal of the study, the availability of mobile applications of the top 10 pharmacy

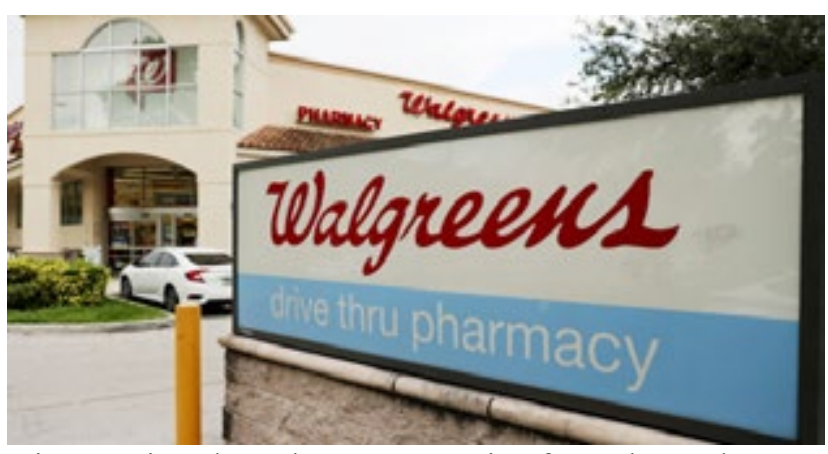

Fig.5. Drive-thru Pharmacy service from the Walgreens Company

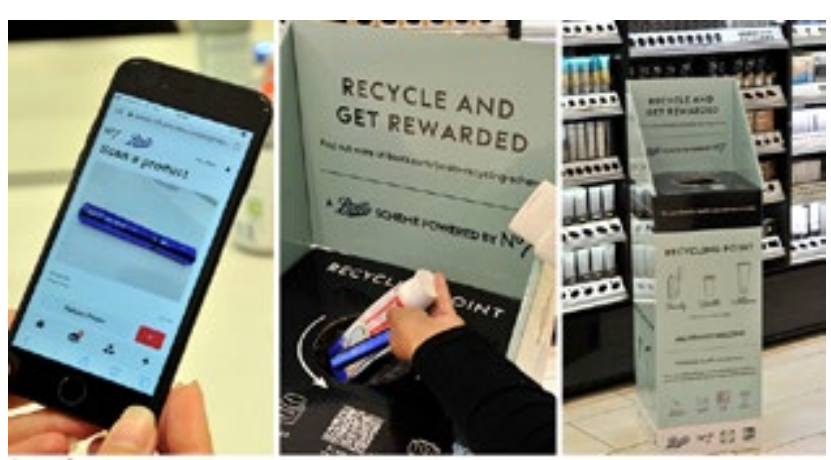

Fig.6. Utilization of used containers with the Boots application

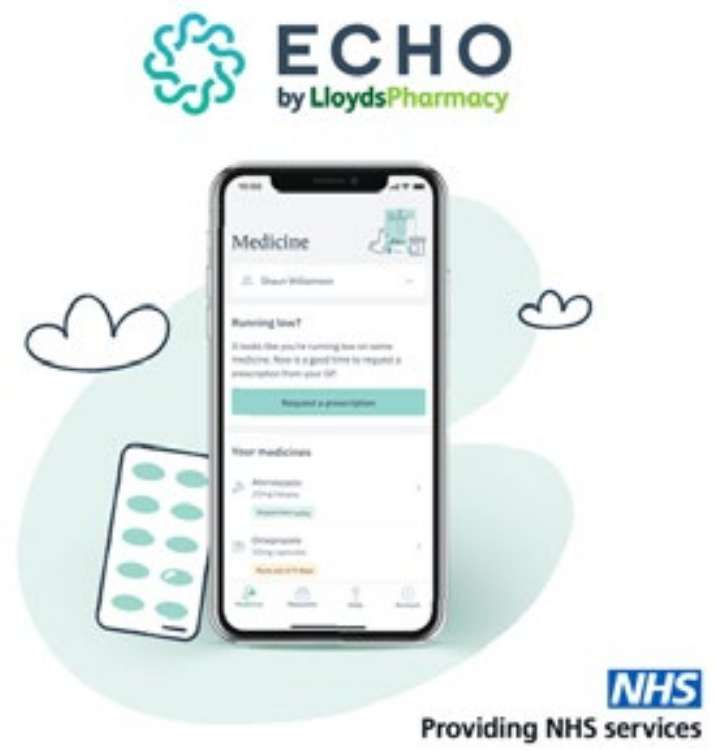

Fig.7. Echo by LloydsPharmacy application interface

chains in Ukraine by market share was analyzed and their main functions were considered (Table 3 ).

According to this research, pharmacy chains such as "We wish you health", "Plantain", "Pharmacy", "Healthy family", " $3 \mathrm{i}$ " do not use the mobile application as a modern digital means of communication with potential customers of the pharmacy. The functions of online booking of medicines, search for the nearest pharmacy with the help of a map, and additional information about 


\begin{tabular}{|c|c|c|c|c|c|c|}
\hline $\begin{array}{c}\text { Name of the pharmacy } \\
\text { network }\end{array}$ & $\begin{array}{l}\text { Application } \\
\text { name }\end{array}$ & $\begin{array}{l}\text { Ability } \\
\text { to book } \\
\text { online }\end{array}$ & $\begin{array}{c}\text { Search for } \\
\text { the nearest } \\
\text { pharmacy with } \\
\text { the help of } \\
\text { online maps }\end{array}$ & $\begin{array}{l}\text { Information } \\
\text { about } \\
\text { promotional } \\
\text { offers }\end{array}$ & $\begin{array}{l}\text { Loyalty } \\
\text { program }\end{array}$ & $\begin{array}{l}\text { Additional } \\
\text { information }\end{array}$ \\
\hline $\begin{array}{l}\text { LLC “Apteka-Magnolia" } \\
\text { ("Pharmacy-Magnolia"): } \\
\text { ("Apteka nyzkyh tsin" } \\
\text { ("Low Prices Pharmacy"), } \\
\text { "Kopiyka" ("Penny»), } \\
\text { "Blahodiya" ("Charity")) }\end{array}$ & LIKE (ANC) & + & + & + & + & $\begin{array}{l}\text { Function in } \\
\text { development }\end{array}$ \\
\hline $\begin{array}{l}\text { Private firm "Gamma-55" } \\
\text { ("Apteka 911" ("Pharmacy } \\
911 ”) \text { ) }\end{array}$ & $\begin{array}{l}\text { Apteka911 } \\
\text { (Pharmacy } \\
911)\end{array}$ & + & + & + & $\begin{array}{l}\text { Function } \\
\text { in devel- } \\
\text { opment }\end{array}$ & - \\
\hline $\begin{array}{l}\text { LLC "Pharmastor" } \\
\text { ("Apteka dobroho dnia" } \\
\text { ("Good Afternoon Pharma- } \\
\text { cy"), "1 sotsialna apteka" } \\
\text { ("1st Social pharmacy")) }\end{array}$ & $\begin{array}{l}\text { Apteka } \\
\text { dobroho dnia } \\
\text { (Good day } \\
\text { pharmacy) }\end{array}$ & + & + & + & + & + \\
\hline LLC Med-Service Group & Med-Service & $\begin{array}{l}\text { Function } \\
\text { in devel- } \\
\text { opment }\end{array}$ & + & $\begin{array}{l}\text { Function in } \\
\text { development }\end{array}$ & + & $\begin{array}{l}\text { Function in } \\
\text { development }\end{array}$ \\
\hline $\begin{array}{l}\text { LLC “Market Universal } \\
\text { Ltd." }\end{array}$ & $\begin{array}{l}\text { D/S. Pharma- } \\
\text { cy network }\end{array}$ & + & + & + & + & + \\
\hline
\end{tabular}

Tab.3. Evaluation results of mobile applications of the studied pharmacy networks of Ukraine Source: developed based on studying information from the official websites of companies

special offers and novelties are possible with the help of the official website. Some of the above-mentioned pharmacies cooperate with the Tabletki.ua service.

The app "Like" from LLC "Pharmacy-Magnolia" (brands Pharmacy ANC, Blagodiya, Kopeyka) has all the primary functions that are important for the pharmacy customer: ordering drugs online, a map to find the nearest pharmacy, a loyalty program to accumulate bonuses for the purchase and more. The Apteka 911 mobile application allows pharmacy customers to get an online doctor's consultation on the most common issues, including coronavirus disease and vaccination. An important aspect is a possibility of ordering prescription drugs on the "Affordable Medicines" program (Fig. 8).

Thanks to the program in the smartphone, the patient can receive up-to-date information on the availability of the necessary medicines in the nearest pharmacy, book medicines, and receive them following the schedule of a particular pharmacy. The developers of this application also plan to develop urgent delivery services, a discount program, in the future potential customers of pharmacies will be able to stand in the electronic queue when visiting a pharmacy.

In the application "Good Afternoon Pharmacy" from the company "Pharmastor" each client has a personal account where his/her personal information is stored, as well as the history of purchases and accrual of bonuses, which helps to control his/her expenses and use the bonuses wisely. In addition to the standard functions for mobile applications, there is also a service for reminding about the use of drugs and managing repeat orders in one touch (Fig. 9).

The Medservice network application is currently under development. Customers have the opportunity to find the nearest pharmacy, use the loyalty program, but so far there is no information on special offers, and it is

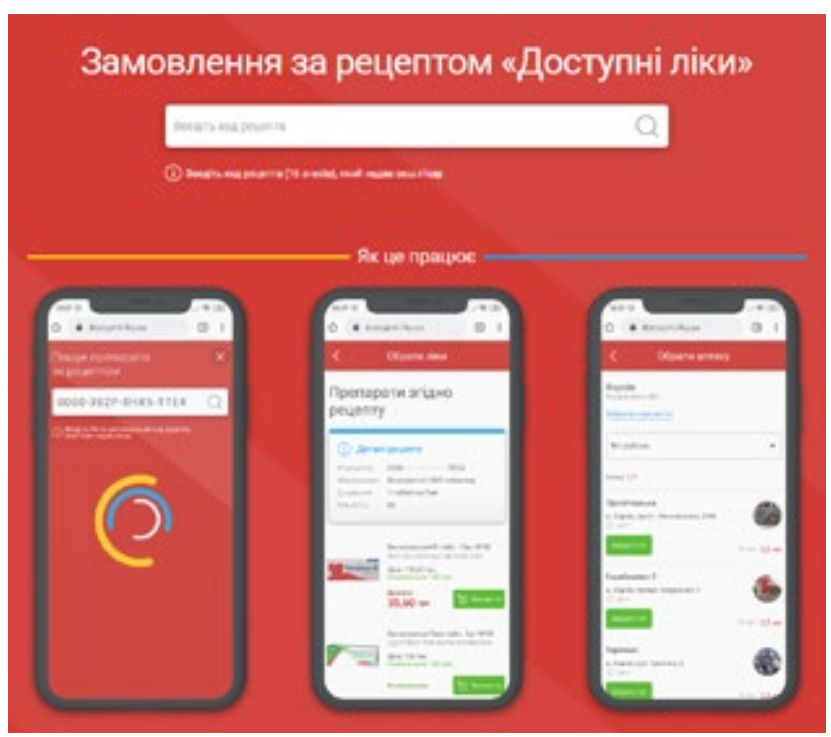

Fig.8. Prescription order "Available medicines" in the application "Apteka911" 


\section{Історія покупок}

\section{Мої нагадування}

\section{Вибране}

Fig.9. Medication reminder function in the "Good Afternoon Pharmacy" mobile application

not possible to book medicines. D.S. Pharmacy Network mobile application of the national network, bearing the same name, contains important advice from doctors and first aid rules for dangerous conditions.

3. Development of an integrated model of a mobile application for Ukrainian pharmacy

After analyzing the foreign experience of leading pharmacy chains and the state of use of mobile applications in domestic pharmacy retail, an integrated model of mobile application of a client-oriented pharmacy was developed to effectively meet the needs of consumers in quality, convenient, and available pharmaceutical care (Fig. 10).

Discussion. Currently, Ukrainian pharmacies do not provide services aimed at counteracting COVID-19, such as testing and vaccination directly in the pharmacy with the possibility of pre-registration online for these services with the help of a mobile application. Today in
Ukraine, online registration for vaccination is possible only thanks to the digital public service "Diya" ("Action"). The problem, first of all, is the lack of a coordinated system of relations between the medical sector and the pharmaceutical sector in our country, because today there are no specially created testing and vaccination points at pharmacies.

However, top managers of domestic pharmacy chains can pay attention to the following services that can be implemented by the use of a mobile application: integration with governmental drug supply programs, such as the reimbursement program "Affordable Medicines", packaging disposal, and rejection of plastic loyalty cards in favor of the application in the smartphone, providing services to patients with disabilities and more. After all, adherence to the principles of socio-ethical marketing using modern digital tools ensures long-term and sustainable development of the pharmacy, its adaptability to changing environmental factors, and its competitiveness.

\section{Research findings.}

1. It is revealed that the studied foreign pharmacy chains actively use mobile applications in their marketing activities. Unlike domestic pharmacies, they additionally provide such services as online registration for testing and vaccination against COVID-19, additional opportunities for the visually impaired, drug disposal, and others.

2. Among the top 10 Ukrainian pharmacy chains by market share, only a half have mobile applications with various functions, among the most custom-

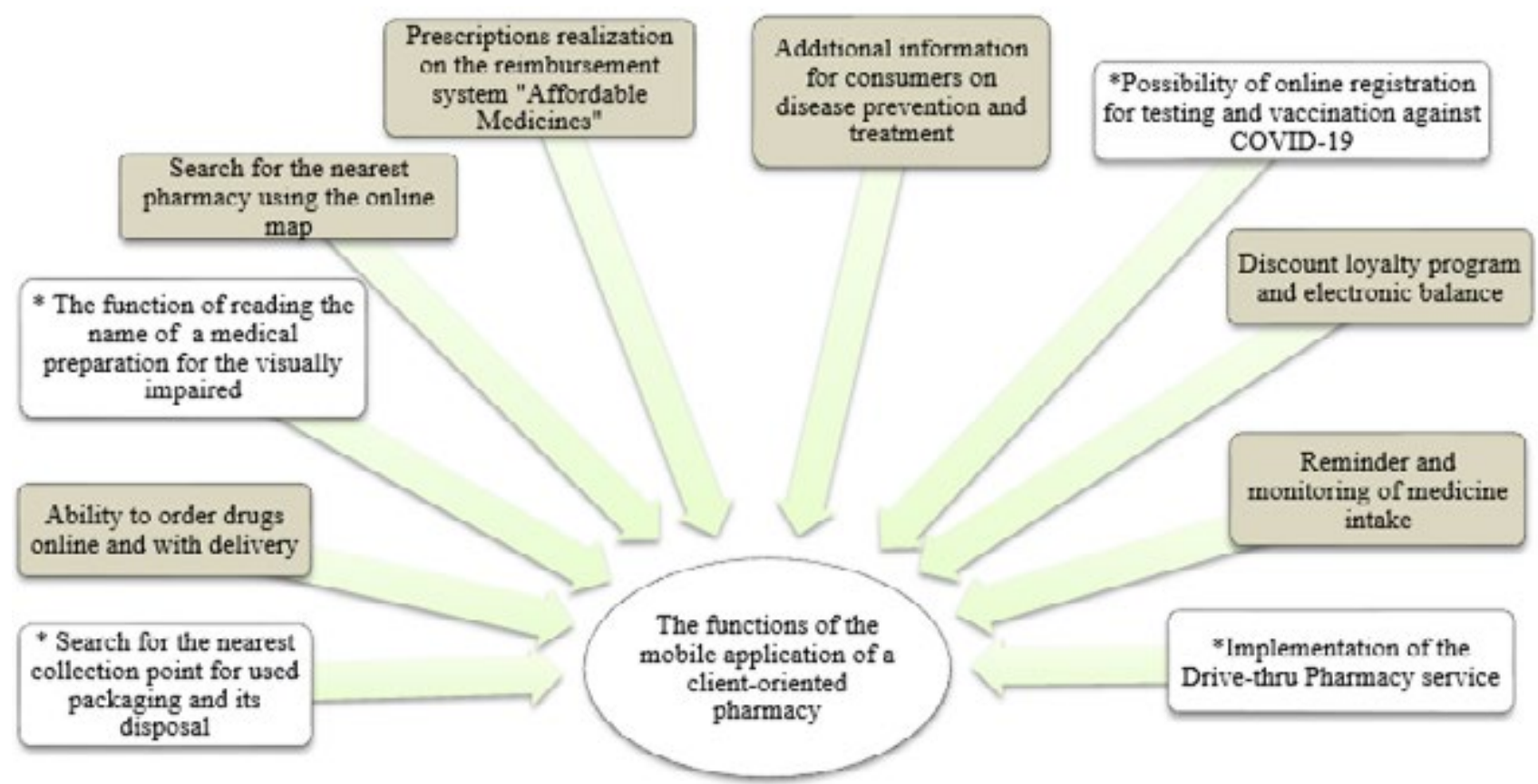

Fig.10. An integrated model of the mobile application of a client-oriented pharmacy.

Source: developed based on a generalization of popular functions of mobile applications of domestic and foreign pharmacies

* marked functions of mobile applications, which are introduced in foreign pharmacy chains, but today have no analogs in Ukraine. 
er-oriented and developed mobile applications to be noted are "Like" from LLC "Pharmacy-Magnolia", "Pharmacy 911" and "Good Afternoon Pharmacy".

3. An integrated model of a mobile application of a modern pharmacy has been developed, aimed at effective interaction of all necessary functions to provide the population with quality, convenient and available pharmaceutical care in the context of holistic marketing.

Financing. This study did not receive external funding.
Conflict of interest. None of the authors received research grants, speaker's fees from any companies and is not a member of commissions.

Authors contribution: concept, methodology, formal analysis - S.N., A.N.; research, resources, data curation, written - S.N., A.N.; original project preparation, review and editing, visualization, supervision, project administration, acquisition of financing - S.N., A.N.

Consent to publication. All authors have read and approved the final version of the manuscript. All authors have agreed to publish this manuscript.

\section{REFERENCES}

About LloydsPharmacy [Electronic resource]

Almost 23 million Ukrainians regularly use the Internet - research [Electronic resource]

Boots: Beauty $\mid$ Health $\mid$ Pharmacy and Prescriptions [Electronic resource]

CVS Health [Electronic resource]

LloydsPharmacy | Online Pharmacy, Prescriptions \& Health [Electronic resource]

Mnushko Z.M., Aliekperova N.V., \& Pestun I.V. (2013). Generalization of the history of development and success factors of the famous US pharmacy network. Current issues of pharmaceutical and medical science and practice, (1), 85-87.

Olkhovska, A., \& Olkhovska, A. B. (2016). Marketing communication and digital technology innovative instruments in promoting pharmaceutical brands in Ukraine and their efficiency estimation. The Pharma Innovation, 5 (9, Part A), 38.

Pharmacy market infrastructure: the evolutionary path of the retail segment consolidation [Electronic resource] // Weekly «Pharmacy». -2020.

Sakhnatska, NM (2019). Problems of online sale of medicines in the context of providing quality and affordable pharmaceutical care to the population [Electronic resource]

Top U.S. pharmacies ranked by prescription drugs market share in 2020 [Electronic resource] // Published by Matej Mikulic

Walgreens: Pharmacy, Health \& Wellness, Photo \& More for You [Electronic resource] World Top Pharmacy Companies List by Market Cap as on Jan 1st, 2020 [Electronic resource]

\section{АНАЛІЗ ВИКОРИСТАННЯ МОБІЛЬНИХ ДОДАТКІВ ЗАКОРДОННИМИ ТА УКРАЇНСЬКИМИ АПТЕЧНИМИ ЗАКЛАДАМИ У РАМКАХ КОНЦЕПЦЇ̈ ХОЛІСТИЧНОГО МАРКЕТИНГУ}

\author{
Сахнацька Наталія ${ }^{1}$, Алєкперова Наталія² \\ ${ }^{1}$ Асистент кафедри організації та економіки \\ фармації, Національний медичний університет \\ імені О.О. Богомольця, м. Київ, Україна \\ ${ }^{2}$ Кандидат фармацевтичних наук, доцент \\ кафедри організації та економіки фармації, \\ Національний медичний університет \\ імені О.О. Богомольця, м. Київ, Україна
}

Анотація. діджиталізація фармацевтичної сфери вимагає використання сучасних маркетингових підходів для надання аптечними закладами якісної та безпечної фармацевтичної допомоги у рамках холістичної концепції маркетингового управління. Перспективним напрямком цифрової трансформації роздрібного ринку ліків є впровадження у діяльність аптечних закладів спеціальних мобільних додатків, що стають безпечною та доступною

\section{АНАЛИЗ ИСПОЛЬЗОВАНИЯ МОБИЛЬНЫХ ПРИЛОЖЕНИЙ ЗАРУБЕЖНЫМИ И УКРАИНСКИМИ АПТЕЧНЫМИ УЧРЕЖДЕНИЯМИ В РАМКАХ КОНЦЕПЦИИ ХОЛИСТИЧЕСКОГО МАРКЕТИНГА}

\author{
Сахнацкая Наталья ${ }^{1}$, Алекперова Наталья ${ }^{2}$ \\ ${ }^{1}$ Ассистент кафедры организации и экономики \\ фармации, Национальный медицинский \\ университет имени А.А. Богомольца, г. Киев, \\ Украина. \\ ${ }^{2}$ Кандидат фармацевтических наук, доцент \\ кафедры организации и экономики фармации, \\ Национальный медицинский университет \\ имени А.А. Богомольца, г. Киев, Украина.
}

Аннотация. диджитализация фармацевтической сферы требует использования современных маркетинговых подходов для предоставления аптечными учреждениями качественной и безопасной фармацевтической помощи в рамках холистической концепции маркетингового управления. Перспективным направлением цифровой трансформации розничного рынка лекарств является внедрение в деятельность 
платформою реалізації лікарських засобів населенню.

Основною метою проведеного дослідження $\epsilon$ аналіз особливостей надання фармацевтичних послуг за допомогою мобільних додатків закордонних та вітчизняних аптечних мереж.

У дослідженні було використано контент-аналіз, аналіз електронних ресурсів, системний та логічний аналізи, а також метод моделювання.

Об'єктом дослідження було обрано американські мережі аптек CVS Pharmacy та Walgreens, британську мережу аптек Boots, яка з 2014 є частиною міжнародної корпорації Walgreens Boots Alliance, LloydsPharmacy, яка має понад 1400 аптек по усій Великобританії, а також 10 аптечних мереж України за обсягами товарообігу за підсумками січня-жовтня 2020 року.

В статті представлено результати аналізу мобільних додатків закордонних аптечних мереж, згідно 3 якими, світові лідери роздрібного ринку ліків вже тривалий час використовують у своій маркетинговій діяльності даний цифровий інструмент. Також було проаналізовано мобільні додатки аптечних закладів України. Виявлено, що, на відміну від вітчизняних аптечних закладів, аплікації закордонних аптек додатково надають такі послуги як онлайн реєстрація на тестування та вакцинацію проти COVID-19, додаткові можливості для людей з вадами зору, утилізація лікарських засобів та інші.

Розроблена інтегрована модель мобільного додатку сучасного аптечного закладу, спрямована на ефективну інтеграцію усіх необхідних функцій 3 метою забезпечення населення якісною, зручною та доступною фармацевтичною допомогою у контексті холістичного маркетингу. Перспективними напрямами подальших досліджень $є$ обгрунтування доцільності використання таких цифрових інструментів, як веб-сайти аптек, сторінки у соціальних мережах та їх роль у холістичний концепції управління сучасним аптечним закладом.

Результати проведеного дослідження можуть бути корисними фахівцям фармацевтичної галузі для використання у практичній фармації.

Ключові слова. телемедицина, оцінка лікарських засобів, мобільний додаток, фармацевтичні препарати, фармація. аптечных заведений специальных мобильных приложений, которые становятся безопасной и доступной платформой реализации лекарственных средств населению.

Главной целью исследования является анализ особенностей предоставления фармацевтических услуг с помощью мобильных приложений зарубежных и отечественных аптечных сетей.

В исследовании были использованы контент-анализ, анализ электронных ресурсов, системный и логический анализы, а также метод моделирования.

Объектом исследования стали американские аптечные сети CVS Pharmacy и Walgreens, британская сеть аптек Boots, которая с 2014 является частью международной корпорации Walgreens Boots Alliance, LloydsPharmacy, которая имеет более 1400 аптек по Великобритании, а также 10 аптечных сетей Украины по объемам товарооборота по итогам января-октября 2020 года.

В статье представлены результаты анализа мобильных приложений зарубежных аптечных сетей, которые показали, что мировые лидеры розничного рынка лекарств уже длительное время используют в своей маркетинговой деятельности данный цифровой инструмент. Также были проанализированы мобильные приложения отечественных аптечных заведений. Выявлено, что, в отличие от отечественных аптечных учреждений, аппликации иностранных аптек дополнительно предоставляют такие услуги как онлайн регистрация на тестирование и вакцинацию против COVID-19, дополнительные возможности для слабовидящих, утилизация лекарственных средств и другие.

Разработана интегрированная модель мобильного приложения современного аптечного учреждения, направленная на эффективную интеграцию всех необходимых функций для обеспечения населения качественной, удобной и доступной фармацевтической помощью в контексте холистического маркетинга. Перспективными направлениями дальнейших исследований являются обоснование целесообразности использования таких цифровых инструментов, как веб-сайты аптек, страницы в социальных сетях и их роль в холистический концепции управления современным аптечным учреждением.

Результаты исследования могут быть полезны специалистам фармацевтической отрасли для использования в практической фармации.

Ключевые слова. телемедицина, оценка лекарственных средств, мобильное приложение, фармацевтические препараты, фармация. 